\title{
PENINGKATAN AKTIVITAS BELAJAR MATEMATIKA PESERTA DIDIK KELAS XI KR3 SMK NEGERI 3 YOGYAKARTA MELALUI PEMBELAJARAN KOOPERATIF TWO STAY TWO STRAY
}

\author{
Arga Daniati \\ SMK Negeri 3 Yogyakarta \\ Email: adaniati@gmail.com
}

\begin{abstract}
Abstrak
Berdasarkan data aktivitas belajar siswa masih rendah maka dilakukan penelitian dengan melakukan tindakan untuk meningkatkan aktivitas belajar Matematika. Prosedur dalam penelitian ini meliputi perencanaan, pelaksanaan dan pengamatan (observasi), dan refleksi. Subyek penelitian adalah siswa kelas XI KR 3 SMK N 3 Yogyakarta tahun pelajaran 2013/2014 semester 4 sebanyak 24 orang. Data diperoleh menggunakan lembar observasi, angket, lembar kerja siswa, serta tes. Penelitian ini menerapkan model pembelajaran Kooperatif Two Stay Two Stray dengan 6 kelompok yang masing-masing terdiri atas 4 orang. Hasil penelitian menunjukkan bahwa (1) Siswa yang aktif terlibat dalam aktivitas belajar $77,08 \%$; (2) siswa yang menyelesaikan soal dengan benar 77,35 \% dan (3) siswa yang mencapai nilai diatas kriteria ketuntasan belajar minimum sebanyak 87,5\%. Penerapan model pembelajaran Kooperatif Two Stay Two Stray dapat meningkatkan aktivitas belajar dan prestasi belajar siswa kelas pada kompetensi grafik fungsi eksponen dan logaritma serta limit fungsi.
\end{abstract}

Kata kunci: aktivitas belajar, prestasi belajar dan pembelajaran Kooperatif Two Stay Two Stray.

\section{ENHANCING LEARNING ACTIVITIES IN MATHEMATICS FOR STUDENTS CLASS XI KR3 AT SMKN 3 YOGYAKARTA USING COOPERATIVE LEARNING TWO STAY TWO STRAY}

\begin{abstract}
Based on the low participation of the student during the classroom activities, this study aimed to improve students' participation and academic achievement on Mathematics. The procedures of this study consisted of planning, implementation, observation, and reflection. There were 24 students of Class XI KR 3 SMK N 3 Yogyakarta 2013/2014 participated in this study. Data were obtained through observation sheets, student worksheets, test, and notes. This study implemented a Cooperative learning model action at Two Stay Two Stray. The students were divided into 6 groups (each group consisted 4 students). The results revealed that (1) the students who actively participated in the classroom activities are 77.08\%; (2) the students who passed the test 77.35\%, and (3) the students who passed the
\end{abstract}


minimum criteria for the study are $87.5 \%$. It can be concluded that implementing Cooperative Learning, Two Stay Two Stray model, is effective to enhance students' participation and academic achievement in mathematics.

Keywords: learning activities, Cooperative learning, academic achievements, Two Stay Two Stray.

\section{PENDAHULUAN}

Matematika adalah salah satu mata pelajaran dan merupakan ilmu dasar (basic science) yang penting sebagai pembimbing pola pikir maupun sebagai pembentuk sikap. Peserta didik memerlukam matematika untuk memecahkan masalah dalam kehidupan sehari-hari. Selain itu agar peserta didik mampu mengikuti pelajaran matematika lebih lanjut, untuk membantu memahami bidang studi lain, agar peserta didik dapat berpikir logis, kritis dan praktis serta bersikap positif dan berjiwa kreatif (Suherman, 2001, hal. 58).

Hal penting yang merupakan bagian dari tujuan pembelajaran matematika yaitu menumbuhkan kemampuan berpikir kritis (Suherman, 2001, hal. 60). Menurut Ennis dan Costa, berpikir kritis merupakan suatu proses penggunaan kemampuan berpikir secara efektif yang dapat membantu seseorang untuk membuat, mengevaluasi serta mengambil keputusan tentang apa yang diyakini atau dilakukan (Suryadi, 2008, hal. 20). Pengertian kemampuan berpikir kritis di atas tampak bahwa sangat diperlukan dalam menghadapi suatu masalah.

Oleh karena itu matematika diharapkan dapat dikuasai oleh peserta didik di sekolah. Namun pelajaran matematika selalu dianggap sulit dan ditakuti oleh peserta didik sehingga sangat berdampak pada rendahnya prestasi belajar peserta didik. Hal ini juga terjadi di SMKN 3 Yogyakarta. Berdasarkan observasi awal penelitian pada SMKN 3 Yogyakarta melalui wawancara dengan beberapa pendidik mata pelajaran matematika bahwa penguasaan peserta didik terhadap materi pelajaran matematika masih tergolong rendah salah satunya pada standar kompetensi Fungsi dan Grafik serta Limit Fungsi. Hal ini juga terlihat dengan rata-rata ulangan harian pada materi sebelumnya dari peserta didik kelas XI tahun ajaran 2012/2013 belum mencapai Kriteria Ketuntasan Minimal yaitu 70. Pendidik kelas XI tersebut mengungkapkan bahwa peserta didik masih kesulitan mengerjakan soal-soal Fungsi dan Grafik serta Limit Fungsi sehingga peserta didik tidak dapat menentukan penyelesaian yang tepat. Selain itu peserta didik juga masih sulit mengerjakan soal yang sedikit saja berbeda dengan contoh soal yang diberikan oleh pendidik. 
Berdasarkan keadaan yang ada maka perlu adanya perubahan paradigma dalam menelaah proses belajar peserta didik dan interaksi antara peserta didik dan pendidik. Sudah seyogyanyalah kegiatan belajar mengajar lebih mempertimbangkan peserta didik. Alur proses belajar tidak harus berasal dari pendidik menuju peserta didik. Peserta didik bisa juga saling mengajar dengan sesama peserta didik yang lainnnya. Bahkan, banyak penelitian menunjukkan bahwa pengajaran oleh rekan sebaya (peer teaching) ternyata lebih efektif daripada pengajaran oleh pendidik. Sistem pengajaran yang memberi kesempatan kepada anak didik untuk bekerjasama dengan sesama peserta didik dalam tugas-tugas yang terstruktur disebut sebagai sistem "pembelajaran gotong royong" atau cooperative learning. Dalam sistem ini, pendidik bertindak sebagai fasilitator.

Sehubungan dengan keunggulan tersebut maka peneliti mencoba menerapkan model pembelajaran kooperatif tipe Two Stay Two Stray untuk meningkatkan aktivitas belajar matematika dalam penguasaan konsep matematika yang akan membawa dampak pada peningkatan prestasi belajar matematika. Oleh karena itu, penelitian ini bertujuan untuk meningkatkan aktivitas dan prestasi belajar matematika peserta didik kelas XI Kendaraan Ringan 3 SMK Negeri 3 Yogyakarta tahun pelajaran 2013/2014 melalui pembelajaran kooperatif tipe Two Stay Two Stray.

\section{METODE PENELITIAN}

Penelitian ini merupakan penelitian tindakan kelas (PTK) yang dilaksanakan di SMKN 3 Yogyakarta. Subyek tindakan adalah peserta didik kelas XI KR 3 (Kendaraan Ringan) tahun pelajaran 2013/2014 yang berjumlah 24 orang yang seluruhnya putra. Penelitian dilakukan sebanyak 2 siklus yang masing-masing terdiri dari 3 pertemuan. Setiap 1 siklus pelaksanaan tindakan kelas terdiri dari perencanaan, pelaksanaan, evaluasi, dan refleksi.

Metode pengumpulan data ada 3, yaitu: pengamatan untuk aktivitas belajar matematika, angket untuk aktivitas belajar matematika siswa, dan tes (pretes diawal siklus dan postes diakhir siklus). Data yang terkumpul selanjutnya dianalisis untuk menentukan keberhasilan pelaksanaan tindakan terhadap siswa. Kriteria yang digunakan untuk menentukan keberhasilan tindakan yang dilakukan adalah sebagai berikut: 
Tabel 1. Kriteria Kemampuan Penyelesaian soal Berdasarkan Prosentase Hasil Tes*

\begin{tabular}{ccc}
\hline No. & Prosentase Hasil Tes & Kriteria \\
\hline 1 & $89 \%<\mathrm{x} \leq 100 \%$ & Sangat Tinggi \\
2 & $79 \%<\mathrm{x} \leq 89 \%$ & Tinggi \\
3 & $64 \%<\mathrm{x} \leq 79 \%$ & Sedang \\
4 & $54 \%<\mathrm{x} \leq 64 \%$ & Rendah \\
5 & $\leq 54 \%$ & Sangat Rendah
\end{tabular}

*Diadopsi dari : Wayan dan Sunartana dalam Fety Herira A hal. 35

$\mathrm{x}=$ prosentase hasil tes.

Tindakan dikatakan berhasil jika:

1. Banyaknya peserta didik melakukan aktivitas belajar matematika mencapai $67 \%$.

2. Kemampuan menyelesaikan soal dengan benar mencapai $67 \%$.

3. Banyaknya peserta didik yang mengalami peningkatan prestasi belajar mencapai $67 \%$.

\section{HASIL DAN PEMBAHASAN}

Sebelum melaksanakan siklus I, peneliti melaksanakan kegiatan pra siklus I (tabel 2):

Tabel 2. Kegiatan Pra penelitian Tindakan Kelas Siklus I

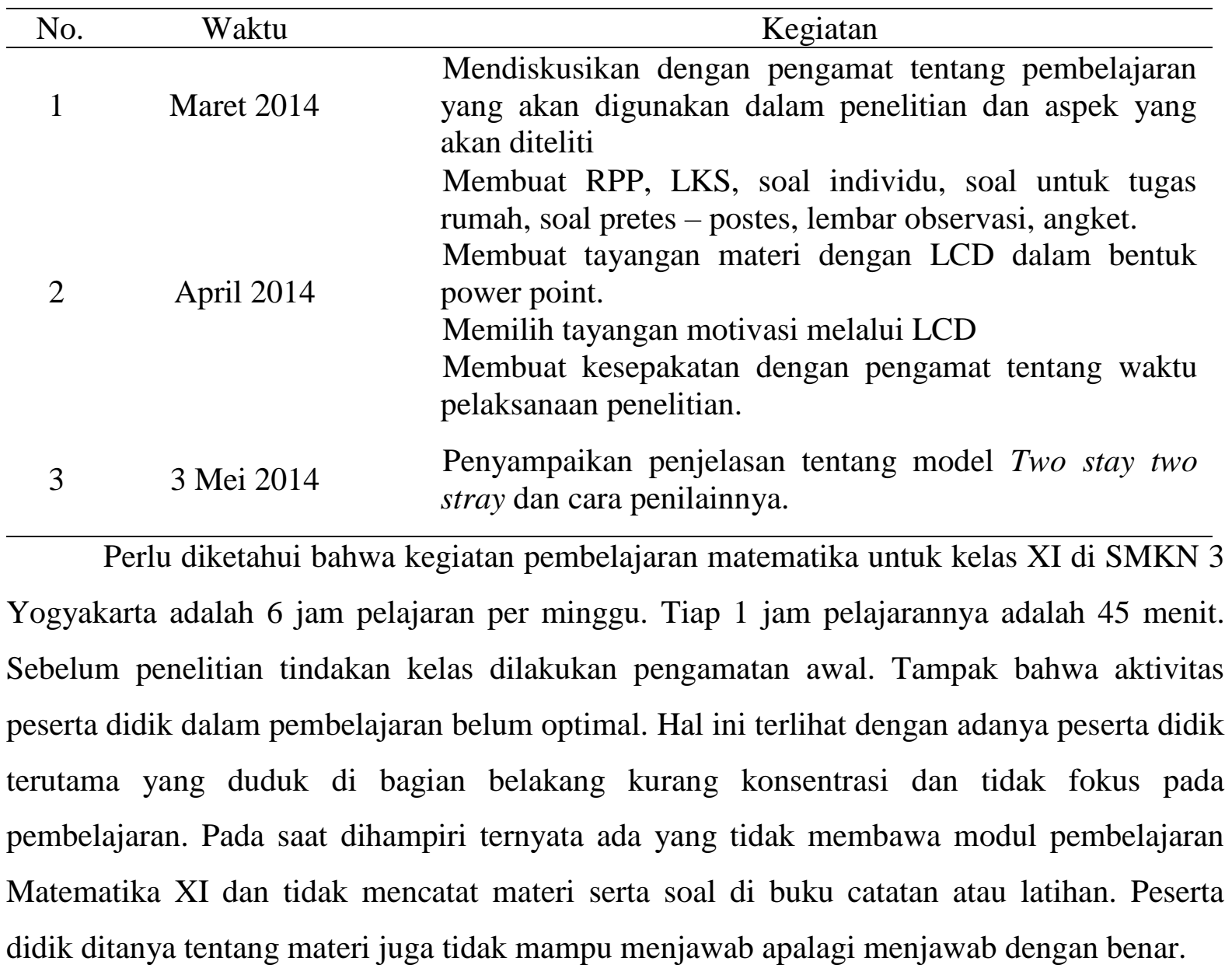


Kemampuan berpikir kritis peserta didik belum tampak. Pada saat pemberian contoh soal dengan tanya jawab peserta didik mampu menyelesaikan soal tersebut. Namun waktu diberi soal dengan materi yang sama tapi variasi yang berbeda peserta didik tidak bisa menyelesaikannya dengan benar. Tes materi sebelumnya diperoleh rata-rata nilai 69,9 dengan nilai terendah 33 tertinggi 80 dengan simpangan baku 10, 039. Dengan KKM (Kriteria Ketuntasan Minimal) 75 ternyata ada 9 peserta didik yang sudah tuntas atau memenuhi KKM (tabel 3).

Tabel 3. Hasil ulangan sebelum penelitian

\begin{tabular}{lllrc}
\hline - Jumlah peserta test & $:$ & 24 orang & Jumlah : & 1670 \\
- Jumlah yang tuntas & $:$ & 9 orang & Terkecil : & 33 \\
- Jumlah yang tidak tuntas & $:$ & 15 orang & Terbesar : & 80 \\
- Jumlah di atas rata-rata & $:$ & 17 orang & Rata-Rata : & 69,6 \\
- Ketuntasan Klasikal & $:$ & $37,5 \%$ & Simpangan Baku : & 10,039 \\
\hline
\end{tabular}

Selanjutnya, peneliti membuat jadwal pelaksanaan tindakan kelas untuk siklus I (tabel 4).

Tabel 4. Jadwal Pelaksanaan Penelitian Kelas Siklus I

\begin{tabular}{clcl}
\hline Pert. & Hari, tanggal, & Waktu & Materi \\
\hline 1 & 14 Mei 2014 & $08.30-10.00$ & 1. Menerapkan konsep Fungsi kuadrat \\
2 & 17 Mei 2014 2013 & $08.30-10.00$ & $\begin{array}{l}\text { 1. Menerapkan konsep fungsi } \\
\text { eksponen dan logaritma }\end{array}$ \\
\hline
\end{tabular}

Pada tahap tindakan, pendidik melaksanakan proses pembelajaran menyesuaikan RPP yang telah dibuat yaitu dengan pembelajaran kooperatif tipe two stay two stray dan menggunakan lembar kerja peserta didik. Selama pembelajaran berlangsung peneliti dibantu pengamat dalam mengisi lembar observasi. Pada siklus I pembelajaran dilaksanakan 2 kali pertemuan.

Kegiatan pembelajaran dengan metode kooperatif tipe two stay two stray dimulai dengan pendahuluan yang meliputi: (1) Pendidik menyampaikan salam pembuka. (2) mengecek kehadiran peserta didik. Salah satu siswa tidak hadir karena sakit. Pendidik mengajak peserta didik lain mendo'akan siswa yang sakit supaya cepat sembuh. (3) Peserta didik dikondisikan untuk dapat dengan mudah membentuk kelompok diskusi sesuai kelompok yang sudah ditentukan. Peserta didik yang nanti "bertamu" ke kelompok lain adalah yang memiliki 2 nomor presensi terbesar. (4) Pendidik memberi motivasi dengan menayangkan kisah "Katak Kecil" melalui LCD. (5) Pendidik menyampaikan tujuan dari materi pembelajaran 
Menerapkan Fungsi Kuadrat. (6) Pendidik menyampaikan soal pretes dan lembar jawabnya. Peserta didik diingatkan untuk mengerjakan tanpa kerja sama dan tanpa melihat diktat atau catatan. Pada tahap pendahuluan ternyata memerlukan waktu 40 menit berarti lebih 10 menit dari yang direncanakan.

Kegiatan inti pada tahap penyampaian materi ini peserta didik dengan tayangan materi yang berupa power point mengamati, mengumpulkan informasi dari soal kontekstual yang dapat diselesaikan dengan mencari nilai ekstrem dari fungsi kuadrat. Pendidik juga menyampaikan pendekatan atau metode ilmiah dalam menyelesaikan soal yang terdiri dari 5 langkah yaitu: mengamati, menanya, mengumpulkan informasi, mengasosiasi, dan mengkomunikasikan. Pada model ini disajikan terlebih dahulu soal-soal sehari-hari (kontekstual). Peserta didik secara kooperatif dengan pendekatan ilmiah dapat menemukan sendiri penyelesaian masalahnya. Pendidik sebagai fasilitator yang membimbing dalam diskusi hingga dapat mengkomunikasikan hasilnya.

Pada tahap kooperatif tipe two stay two stray, pendidik memberi lembar LKS pada tiap kelompok. Setelah 10-15 menit maka peserta didik "bertamu" pada kelompok lain selama 5 menit. Pada 5 menit terakhir digunakan untuk membuat kesimpulan kelompok. Saat "bertamu", salah satu siswa anggota kelompok 1 sempat beberapa kali kembali ke kelompoknya karena mengetahui temannya sebagai "tuan rumah" tidak dapat menjawab pertanyaan tamunya. Namun segera kembali "bertamu". Berbeda dengan yang terjadi pada siswa dari kelompok 6 yang justru ternyata mendapatkan informasi untuk menyelesaikan soal dari siswa anggota kelompok 5. Tuan rumah tidak nampak berusaha untuk menulis atau mencatat informasi yang didapat dengan alasan lembar LKS kelompoknya dibawa oleh temannya yang sedang bertamu. Pada dasarnya saat "bertamu" dapat terjadi 2 hal yaitu tamunya yang bertanya dan tuan rumah yang menjawab atau justru sebaliknya tamu yang menjawab pertanyaan tuan rumah.

Setelah itu, setiap siswa diberi tugas individu diberikan berupa LKS yang dikerjakan selama 20 menit. Masing-masing peserta didik megerjakan soal kontekstual yang dapat diselesaikan dengan nilai ekstrem fungsi kuadrat. Diktat matematika XI dapat digunakan sebagai bantuan dalam menyelesaikan soal tersebut. Pendidik menyampaikan tugas rumah dari Diktat Matematika XI C halaman 41 nomor 5. Untuk dikerjakan di rumah pada buku siswa.

Pada tahap penutup, pendidik menyampaikan rencana pembelajaran pada pertemuan ke2 dilanjutkan dengan menanyakan kepada peserta didik tentang pembelajaran yang sudah 
terlaksana. Peserta didik ternyata menghendaki ditayangkan lagi cerita motivasi yang lain. Namun jangan terlalu banyak soal yang diberikan. Pembelajaran ditutup dengan salam oleh pendidik dan penutupan dapat dilaksanakan dalam 10 menit.

Setelah dilaksanan proses pembelajaran dilakukan refleksi untuk menganalisis hasil tindakan. Pada siklus I saat pergantian ke tahap diskusi masih ada siswa yang gaduh. Pada awal siklus II peserta didik diingatkan agar tidak gaduh saat pergantian tahapan. Lembar LKS dibuat sejumlah peserta didik supaya saat "bertamu" sudah membawa hasil diskusi kelompoknya. Pada saat "bertamu" suasana menjadi gaduh. Pada awal siklus II pendidik akan menayangkan kembali aturan "bertamu". Siapa "bertamu" dan ke kelompok mana "bertamunya", menggunakan denah. Pendidik kesulitan dalam mengontrol keterlaksanaan kegiatan "bertamu". Pada siklus II peserta didik akan dibuatkan tanda pengenal yang dikenakan pada baju seragamnya. Papan nama kelompok juga dibuat dengan warna yang sama dengan tanda pengenal masing-masing anggota kelompok. Diharapkan pada saat "bertamu" pada kelompok lain akan mudah dikontrol oleh pendidik. Peserta didik sudah berdiskusi dengan serius. Meskipun ada beberapa anak yang masih pasif atau hanya menurut dengan temannya tanpa bertanya atau memberikan pendapatnya. Pada siklus II peserta didik diingatkan untuk lebih aktif bertanya, menjawab dan mencatat. Semua kelompok secara bergantian mengajukan pertanyaan. Pendidik menjawab pertanyaan peserta didik yang menanyakan materi maupun hanya sekedar meyakinkan tentang soal yang telah dibuat. Pendidik berusaha adil dalam membimbing kelompok-kelompok yang bertanya. Pelaksanaan pembelajaran kooperatif kooperatif tipe Two Stay Two Stray sudah berjalan, tetapi kurang optimal. Supaya optimal maka pada siklus 2 anggota dengan 2 nomor presensi besar (C dan D) yang bertamu. Untuk C bertamu pada kelompok sebelumnya dan D bertamu pada kelompok sesudahnya.

Tabel 5. Daftar anggota kelompok saat Two Stray

\begin{tabular}{|c|c|c|c|c|}
\hline $\begin{array}{c}\text { Kelompok } \\
\text { Asal }\end{array}$ & & $\begin{array}{l}\text { sota } \\
\text { ok Saat } \\
\text { Stray }\end{array}$ & Nama & $\begin{array}{c}\text { Warna Kartu } \\
\text { Identitas }\end{array}$ \\
\hline \multirow{4}{*}{ A } & A & 1 & Narendra Rangga D & Merah \\
\hline & A & 2 & Nuri Indra Saputra & Merah \\
\hline & B & 3 & Nugroho Zein Citra & Orange \\
\hline & $\mathrm{F}$ & 4 & Nur Imam Syah & Pink \\
\hline \multirow{4}{*}{ B } & B & 1 & Nangapo & Orange \\
\hline & B & 2 & Pri Andono & Orange \\
\hline & $\mathrm{C}$ & 3 & Parji Nur Cahyo S & Kuning \\
\hline & A & 4 & Mohamad Rudi A & Merah \\
\hline $\mathrm{F}$ & $\mathrm{F}$ & 1 & Muhammad Septiaji & Pink \\
\hline
\end{tabular}




\begin{tabular}{llll}
\hline F & 2 & Nanang Ely H & Pink \\
A & 3 & Prasetya Agus S & Merah \\
E & 4 & Ridwan Alam & Biru \\
\hline
\end{tabular}

Kelancaran pembelajaran sudah terjadi yang artinya tidak ada halangan yang berarti. Pergantian materi dapat terjadi dengan baik. Kendala yang terjadi adalah waktu tiap tahapan belum sesuai rencana atau masih kurang waktu. Suasana pembelajaran masih biasa-biasa saja. Untuk siklus II pendidik akan menyampaikan materi dengan cara yang lebih menyenangkan, serius namun tidak tegang dan tetap ceria. Sehingga tidak ada lagi peserta yang malas dalam mengikuti pembelajaran atau meletakkan kepalanya dimeja.

Deskripsi Pelaksanaan Siklus II dilaksanakan seperti pada tabel

Tabel 6. Jadwal Pelaksanaan Penelitian Kelas Siklus II

\begin{tabular}{|c|c|c|c|}
\hline Pert. & Hari, tanggal, & Waktu & Materi \\
\hline 1 & 28 Mei 2014 & -10.00 & $\begin{array}{l}\text { 1. Menerapkan konsep Fungsi } \\
\text { Trigonometri }\end{array}$ \\
\hline 2 & 31 Mei 2014 & $08.30-10.00$ & $\begin{array}{l}\text { 2. Menerapkan konsep Limit fungsi aljabar } \\
\text { dan trigonometri }\end{array}$ \\
\hline
\end{tabular}

Kegiatan perencanaan ini mempersiapkan segala sesuatu yang akan dilaksanakan pada pelaksanaan penelitian tindakan kelas pada siklus II sesuai dengan hasil refleksi I. Materi yang disampaikan pada pertemuan pertama adalah menerapkan konsep fungsi trigonometri yaitu menggambar grafik fungsi trigonometri sinus dan cosinus.

Materi pertemuan kedua adalah menerapkan konsep limit fungsi aljabar dan trigonometri. LKS 3 adalah menentukan grafik fugsi trigonometri sinus dan cosinus yang dikalikan dengan bilangan bulat, bilangan pecahan, positif dan negatif. Menggunakan bantuan tabel dan sudut-sudut istimewa untuk memudahkan dalam penentuan nilainya juga kemudahan dalam membuat grafiknya. Sebagian tabel sudah terisi untuk membantu/membimbing dalam pengisiannya. Disiapkan pula garis-garis koordinat dengan garis horisontal untuk sudut dalam satuan derajat dan untuk garis vertikal adalah nilai fungsi trigonometrinya. Peserta didik mengisikan pasangan titik-titiknya kemudian menuliskan besar sudut pada garis horisontal dan nilainya pada garis vertikal. Menggunakan bantuan garis putus-putus vertikal dari nilai sudut dan garis putus-putus horisontal dari nilai fungsi trigonometrinya maka akan diperoleh titik-titik bantu. Titik-titik tersebut kemudian dihubungkan sehingga membentuk grafik fungsi trigonometri yang diinginkan.

Soal individu pada pertemuan ke-1 adalah mengenai penerapan fungsi trigonometri yaitu menggambar grafik fungsi trigonometri. Soal yang diberikan setara dengan soal pada LKS 3 . 
Untuk soal individu ke-2 adalah menentukan nilai limit aljabar dengan variabel mendekati tak berhingga dan limit fungsi trigonometri untuk variabel mendekati nol.

Lembar Observasi digunakan untuk mendapatkan data (1) aktivitas belajar, (2) kelancaran pembelajaran, (3) suasana pembelajaran dan (4) hasil belajar. Masing-masing terdiri dari 3 hal yang diamati. Lembar Observasi ini diisi oleh pengamat dan peneliti dengan mengamati peserta didik dalam pembelajaran. Lembar observasi yang digunakan pada siklus II ini sama persis dengan yang digunakan pada siklus I.

Kegiatan yang dilakukan pada siklus II terdiri dari: Pendahuluan (1) Pendidik memberi salam pembuka dan peserta didik menjawab salam. (2) Pendidik meminta pada peserta didik untuk menanda tangani daftar hadir. (3) Pendidik menyampaikan tujuan dari materi grafik fungsi trigonometri. (4) Pendidik menyampaikan soal pretes 2 dan lembar jawabnya. Peserta didik diingatkan untuk mengerjakan tanpa kerja sama dan tanpa melihat diktat atau catatan dalam waktu 30 menit. (5) Pendidik menyampaikan apersepsi tentang nilai-nilai sudut istimewa pada kuadran satu menggunakan bantuan LCD proyektor dalam waktu 5 menit.

Selanjutnya kegiatan inti dilaksanakan dengan pendidik menyampaikan materi limit funsi trigonometri dengan variabel mendekati tak berhingga dan limit fungsi trigonometri untuk variabel mendekati nol dengan tanya jawab menggunakan bantuan LCD proyektor. Peserta didik duduk dalam kelompok untuk persiapan diskusi mengenai materi di yang tersedia di LKS 3. Peserta didik disarankan menggunakan pensil penggaris dalam langkah pembuatan grafik. Situasi diskusi yang berjalan sudah berjalan dengan tertib termasuk pada saat perpindahan. Peserta didik kembali lagi pada kelompoknya untuk menyampaikan hasil kunjungannya. Pendidik membimbing kelompok-kelompok yang memerlukan secara bergantian.

Pada tahapan penutupan, pendidik memberikan ulasan dari hasil LKS 3 dan menyampaikan rencana pembelajaran pada pertemuan ke-2. Pendidik menanyakan kepada peserta didik tentang pembelajaran yang sudah terlaksana. Pembelajaran ditutup dengan salam oleh pendidik.

Pertemuan kedua dimulai dengan kegiatan pendahuluan seperti pada pertemuan sebelumnya. Selanjutnya kegiatan inti dengan pendidik menyampaikan materi limit fungsi aljabar untuk variabel mendekati bilangan real dan membahas contoh soal. Salah satu peserta didik menyampaikan pendapatnya tentang pembahasan yang telah disampaikan pendidik. Pendidik mengarahkan peserta didik membuat kesimpulan tentang langkah-langkah 
penyelesaian limit fungsi aljabar untuk variabel bilangan real. Pada tahap ini dilakukan selama 10 menit.

Tahap kooperatif tipe two stay two stray, peserta didik duduk dalam kelompoknya dan menerima lembar LKS 4 dari pendidik yang berisi Limit fungsi aljabar untuk variabel mendekati tak berhingga dan limit trigonometri untuk variabel mendekati nol. Pada LKS 4 tersebut peserta didik diminta untuk mengamati dan memahami pengertian, rumus dan lagkah-langkah yang telah disediakan untuk menyelesaikan soal. Selanjutnya, setelah diskusi pada kelompok asal selesai kemudian tiap 2 anggota kelompok berpindah pada kelompok yang berbeda sesuai dengan aturan yang telah ditentukan. Warna papan nama antara kelompok yang bertamu dan menjadi tuan rumah berbeda untuk memudahkan identifikasi. Diskusi di kelompok asal dilanjutkan dengan peserta yang berpindah kembali pada kelompok asal dan menyampaikan informasi yang diperoleh saat di kelompok lain selama 5 menit.

Penutupan, peserta didik kembali duduk pada bangku masing-masing untuk mengerjakan postes selama 30 menit. Setelah mengerjakan postes, peserta didik diminta mengisi angket aktivitas siswa. Pembelajaran diakhiri dengan salam.

Observasi dilakukan oleh pengamat dengan mengisi lembar observasi pada tiap pertemuan. Peserta didik mengisi angket tentang aktivitas belajar matematika dan kuisioner tentang materi dan model pembelajaran yang digunakan dalam penelitian ini. Pengamat mengisi catatan lapangan tentang kejadian-kejadian penting.

Peneliti melakukan refleksi siklus II dengan hasil sebagai berikut: (1) Pembagian waktu tiap-tiap tahap sudah lebih sesuai dengan waktu yang direncanakan. (2) Perpindahan peserta sudah dipahami peserta didik sehingga tidak menimbulkan kegaduhan. (3) Penggunaan papan nama dan kartu identitas denganwarna yang berbeda pada tiap kelompok memudahkan pendidik dalam mengontrol terlaksananya perpindahan yang anggota kelompok saat diskusi two stray dengan benar. (4) Beberapa kelompok masih memerlukan bimbingan dalam memehami LKS 4. (5) Peserta didik sudah berupaya mengoptimalkan perolehan informasi saat bertamu di kelompok lain. (6) Meskipun demikian masih ada peserta didik yang bertanya saja tanpa memberikan informasi kepada kelompok lain.

Pelaksanaan penelitian tindakan kelas pada siklus I dilaksanaka dengan 2 pertemuan disesuaikan dengan jadwal kelas dan agenda kegiatan sekolah. Alokasi waktu tiap-tiap tahapnya belum dapat ditepati dengan baik sedangkan pada siklus II sudah lebih mendekati waktu yang direncanakan. Pergantian dari diskusi kelompok awal ke kelompok diskusi lain ( bertamunya dua anggota ) dari siklus I ke siklus II dari pertemuan 1 ke pertemuan 2 
berangsur-angsur semakin teratur dan tenang. Pendidik mengingatkan beberapa saat sebelum pergantian dan melakukan pengecekan secara acak pada peserta didik yang seharusnya bertamu ke kelompok lain. Tiap-tiap peserta didik dengan membawa lembar LKS juga mempercepat proses perpindahan kelompok diskusi. Semula peserta didik harus memastikan informasi yang akan ditanyakan atau diketahui untuk bertamu ke kelompok lain sehingga memperlambat proses pergantian diskusi.

Aturan bertamunya dua anggota dengan satu anggota ke kelompok sebelum dan satu anggota lagi kekelompok sesudah diingatkan dan dikontrol secara acak beberapa saat sebelum pelaksanaan. Sehingga suasana lebih teratur dan tenang saat pergantian maupun diskusi. Peserta didik yang menggunakan tanda pengenal dengan warna berbeda untuk tiap kelompoknya memudahkan pendidik mengontrol terlaksananya proses perpindahan dengan benar.

Pada siklus II peserta didik sudah lebih banyak yang bertanya, menjawab dan mengerjakan LKS. Peserta didik yang bertanya kepada pendidik juga lebih banyak lagi sampai harus menunggu giliran untuk dibimbing/dijawab. Dengan kata lain aktivitas belajar sudah meningkat.

Aktivitas belajar matematika pada siklus I sebesar 66,99\% dan pada siklus II sebesar $77.08 \%$ berarti terjadi peningkatan 10,09\% (Diagram 1). Pada siklus I belum mencapai 67\% sedangkan pada siklus II sudah melampaui 67\%. Sehingga dapat dikatakan bahwa tindakan menggunakan pembelajaran kooperatif tipe Two Stay Two Stray berhasil meningkatkan aktivitas belajar matematika siswa kelas XI KR 3 SMK Negeri 3 Yogyakarta tahun pelajaran 2013/2014. Aktivitas belajar matematika tersebut diperoleh dari lembar observasi aktivitas belajar dan angket aktivitas belajar siswa.

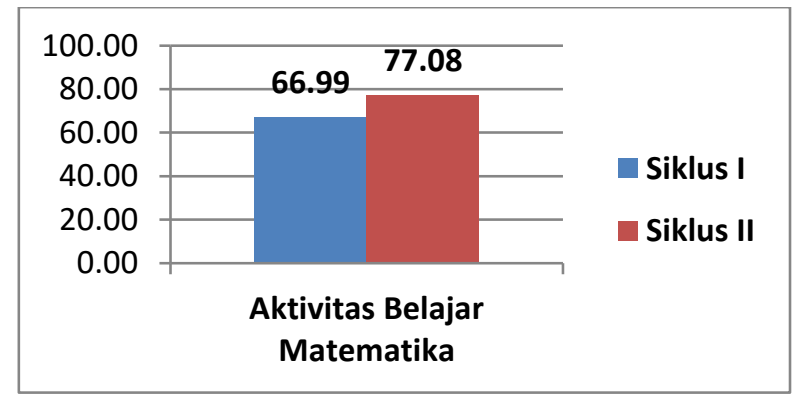

Diagram 1. Aktivitas Belajar Matematika

Penyempurnaan pada siklus II menggunakan hasil refleksi siklus I membuat pendidik dan peserta didik lebih siap dan mampu mengelola waktu sehingga terlaksana sesuai dengan 
rencana. Semua kelompok dapat menyelesaikan LKS 3 dan 4. Nilai postes pada siklus II mengalami peningkatan yang signifikan yaitu mencapai 92,10 sedangkan nilai postes siklus I adalah 72,90 berarti terjadi peningkatan 19,20. Pendidik juga lebih mampu mengelola waktu dan pembelajaran. Siswa lebih berani bertanya, menjawab, berpendapat, cermat, dan kritis. Bahkan situasi pembelajaran dapat berjalan dengan lancar dan ceria.

Kemampuan menyelesaikan soal dengan benar peserta didik yang diperoleh dari instrumen LKS, pretes dan postes pada siklus I mencapai 63,30\% dan pada siklus II mencapai $77,35 \%$ yang berarti terjadi kenaikan $14,05 \%$. Kemampuan menyelesaikan soal dengan benar peserta didik pada siklus II sudah melampaui 67\% sehingga dapat dikatakan bahwa penerapan pembelajaran kooperatif tipe Two Stay Two Stray berhasil meningkatkan kemampuan menyelesaikan soal matematika dengan benar pada peserta didik kelas XI KR 3 SMK Negeri 3 Yogyakarta tahun 2013/2014.

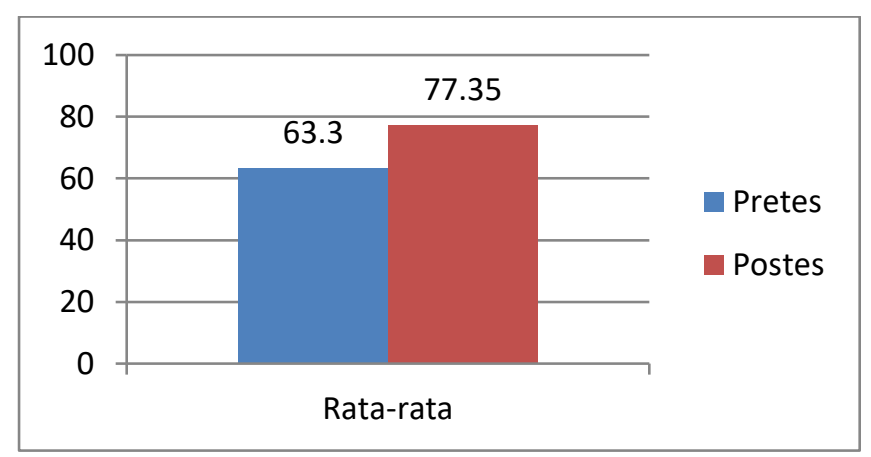

Diagram 2. Nilai Rata-rata Pretes dan Postes pada Siklus I dan II

Banyaknya siswa tuntas belajar pada siklus I sebanyak 10 dari 23 siswa ( 1 peserta didik tidak hadir karena sakit) atau $41 \%$, sedangkan pada siklus II sebanyak 21 dari 24 siswa atau $87,5 \%$. Terjadi peningkatan sebanyak 11 anak atau 46,5\% sedangkan ketuntasan belajar siswa dilihat dari hasil postes. Pencapaian hasil postes pada siklus II sudah melebihi $67 \%$ sehingga dapat dikatakan bahwa penerapan pembelajaran kooperatif tipe Two Stay Two Stray berhasil meningkatkan prestasi belajar matematika peserta didik kelas XI KR 3 Yogyakarta tahun 2013/2014.

Peserta didik yang nilai tugas individu belum mencapai KKM atau yang belum tuntas diminta untuk mengerjakan ulang tugas individu untuk nomor-nomor yang masih salah dan menggunakan caranya. Perbaikan tersebut ditulis pada lembar tugas individu. Sedangkan untuk postes, pendidik menyampaikan pembahasan untuk soal-soal yang nilainya rendah secara klasikal. Dengan terbatasnya waktu karena telah memasuki Ulangan Umum semester 4 
maka perbaikan nilai bagi peserta didik yang belum tuntas pada siklus II dilakukan bersamaan dengan perbaikan nilai setelah ulangan umum semeser 4 .

Dari pembahasan di atas dapat disimpulkan bahwa penerapan pembelajaran kooperatif Two Stay Two Stray pada peserta didik kelas XI KR 3 Yogyakarta tahun pelajaran 2013/2014 dapat meningkatkan aktivitas belajar matematika dan kemampuan menyelesaikan soal dengan benar, hal tersebut menyebabkan meningkatnya prestasi belajar matematika.

\section{PENUTUP}

Setelah menyelesaikan penelitian tindakan kelas maka penulis menyimpulkan bahwa penerapan model pembelajaran kooperatif Two Stay Two Stray dapat meningkatkan keaktifan dan prestasi belajar Matematika peserta didik kelas XI KR 3 SMK Negeri 3 Yogyakarta. Oleh karena itu, model ini dapat terus diterapkan untuk meningkatkan kualitas pembelajaran, khususnya matematika bagi siswa di jurusan Kendaraan Ringan SMKN 3 Yogyakarta.

\section{UCAPAN TERIMAKASIH}

Terima kasih penulis ucapkan kepada Bapak Drs. Aruji Siswanto selaku Kepala Sekolah Menengah Kejuruan Negeri 3 Yogyakarta yang telah memberi fasilitas dan kesempatan sehingga laporan penelitian ini selesai. Bapak Drs. Gunawan Santosa, M. Si yang telah memberikan bimbingan dalam menyelesaikan laporan penelitian. Rekan-rekan pendidik dan tenaga kependidikan pada Sekolah Menengah Kejuruan Negeri 3 Yogyakarta, khususnya kepada teman sejawat yang telah membantu dan memberi pertimbangan pada penyusunan instrumen penelitian yang akan digunakan sebagai alat pengumpul data, serta peserta didik kelas XI KR 3 SMK Negeri 3 Yogyakarta tahun pelajaran 2013/2014 yang telah berpartisipasi dan bekerjasama dengan baik selama menjalani penelitian ini.

\section{DAFTAR PUSTAKA}

Ahmad, R. (2010). Pengelolaan Pengajaran : Sebuah Pengantar Menuju Guru profesional. Jakarta: Rineka Cipta.

Anita, L. (2008). Cooperative Learning. Jakarta: Grasindo.

blogspot.com. (2013). Pengertian Prestasi Belajar.

http://seputarpendidikan003.blogspot.com/2013/07/pengertian-prestasi-belajar.html.

DA88. (2010). Aktivitas Belajar Siswa. http://id.shvoong.com/social-sciences/1961162aktifitas-belajar/\#ixzz2ufwmjWUI: diakses pada tanggal 1 Maret 2014. 
Dalyono. (2009). Psikologi Pendidikan. Jakarta: Rineka Cipta.

Diknas. (2005). Standar Kompetensi 2004 untuk SMP. Jakarta: Depag RI.

Djamarah, S. B. (2002). Strategi Belajar Mengajar. Jakarta: Rineka Cipta.

Een, R. (2012). Penerapan Model Pembelajaran Kooperatif Tipe Two Stay Two Stray Untuk Meningkatkan Aktivitas Belajar Akuntansi Siswa Kelas X Program Keahlian Akuntansi SMK N I Yogyakarta Tahun Ajaran 2011/2012. Yogyakarta: UNY.

Hendra, S. (2009). Menjadi Manusia Pembelajar. Jakarta: PT. Gramedia.

Martinus, Y. (2007). Kiat Membelajarkan Siswa. Jakarta: Gaung Persada Press.

Miftahul, H. (2011). Yogyakarta: Pustaka Pelajar.

Miftahul, H. (2011). Cooperative Learning. Yogyakarta: Pustaka Pelajar.

Ngalim, P. (2010). Psikologi pendidikan. Bandung: Remaja Rosdakarya.

Nur, A. (2006). Model Pembelajaran Kooperatif. Jakarta: Departemen Pendidikan Nasional.

Oemar, H. (2008). Proses Belajar Mengajar. Jakarta: Bumi Aksara.

Rusman. (2011). Model-model Pembelajaran. Jakarta: Raja Grafindo Persada.

Sardiman. (2011). Interaksi dan Motivasi Belajar Mengajar. Jakarta: Grasindo.

Slameto. (2003). Belajar dan Faktor-Faktor yang Mempengaruhinya. Jakarta: Rineka Cipta.

Suherman, E. d. (2001). Strategi Pembelajaran Kontemporer. Bandung: JICA UPI.

Sumadi, S. (2007). Psikologi Pendidikan. Jakarta: Raja Grafindo Persada.

Surya, H. (2009). Menjadi Manusia Pembelajar. Jakarta: PT. Gramedia.

Suryadi, d. (2008). Eksplorasi Matematika Pembelajaran Pemecahan Masalah. Jakarta: Karya Duta Wahana.

Syah, M. (2005). Psikologi Pendidikan dan Pendekatan Baru. Bandung: RemajaRosdkarya. usu.ac.id. (2011). Pengertian Prestasi Belajar. http://repository.usu.ac.id/bitstream/123456789/30314/4/Chapter\%20II.pdf.

Uzer, U. (2006). Menjadi Guru Profesional. Bandung: Remaja Rosdakarya.

Wina, S. (2009). Strategi Pembelajaran Berorientasi Standar Proses Pendidikan. Jakarta: Prenada Media Group. 